DOI: $10.19195 / 0080-3626.61 .8$

EWA ANDRYSIAK, KRZYSZTOF WALCZAK

\title{
ROSYJSKIE KSIĘGOZBIORY KALISKICH GIMNAZJÓW JAKO PRZYKŁAD KOLEKCJI BIBLIOTEKI UNIWERSYTECKIEJ W POZNANIU
}

Potrzeby powstałej w 1919 roku Biblioteki Uniwersytetu Poznańskiego w zakresie literatury polskiej i słowiańskiej. Gimnazja kaliskie i ich księgozbiory. Przewiezienie tych księgozbiorów do Poznania w latach 1922-1923. Ich zawartość i znaczenie dla Biblioteki Uniwersytetu Poznańskiego.

SŁOWA KLUCZOWE: Biblioteka Uniwersytecka w Poznaniu, Kalisz, biblioteki gimnazjalne

\section{WSTĘP}

W zbiorach Biblioteki Uniwersytetu im. Adama Mickiewicza w Poznaniu zachowało się wiele księgozbiorów historycznych, znacznie wzbogacających bieżące gromadzenie, jakie biblioteka ta prowadzi od chwili powstania Uniwersytetu Poznańskiego w 1919 roku. W gruncie rzeczy początki tej liczącej dzisiaj blisko trzy miliony jednostek placówki bibliotecznej związane są z faktem, iż powstała ona w oparciu o budynek i księgozbiór niemieckiej Kaiser-Wilhelm-Bibliothek — Biblioteki Cesarza Wilhelma, założonej w Poznaniu w 1902 roku¹. Celem istnienia tej placówki bibliotecznej, założonej z myślą o skuteczniejszej germanizacji ludności prowincji poznańskiej, wchodzącej ówcześnie w skład Cesarstwa Niemieckiego, było utworzenie księgozbioru, stanowiącego narzędzie umacniania niemczyzny na terenie Wielkopolski, sam zaś księgozbiór tworzony był m.in. z da-

1 Kaiser-Wilhelm-Bibliothek powstała w oparciu o założoną zaledwie osiem lat wcześniej (1894) Bibliotekę Krajową (Landesbibliothek) w Poznaniu, na księgozbiór której złożyły się m.in. zbiory Towarzystwa Historycznego (Historische Gesellschaft des Provinz Posen), Towarzystwa Przyrodniczego (Naturwissenschaftlicher Verein), a także książki innych niemieckich bibliotek — S. Vrtel-Wierczyński, Biblioteka Uniwersytecka w Poznaniu 1919-1929, Poznań 1929, s. 3-4. 
rów społeczeństwa całych Niemiec, przejętego misją germanizacji wschodnich rubieży Cesarstwa i przeciwdziałania polskim zabiegom o utrzymanie tożsamości narodowej tych ziem.

Klęska wojenna Niemiec w listopadzie 1918 roku spowodowała, iż w konsekwencji (w wyniku zwycięskiego powstania wielkopolskiego) znaczna część polskich ziem, niegdyś zajętych przez Królestwo Prus, została odzyskana i weszła w skład II Rzeczypospolitej. Jedną z pierwszych decyzji w wyzwolonym Poznaniu było utworzenie uniwersytetu, o którego powstanie miasto zabiegało bez skutku co najmniej od XVI wieku. Naturalną koleją rzeczy zarówno budynek, jak i księgozbiór Kaiser-Wilhelm-Bibliothek (liczący w tym czasie już ok. 270 tysięcy woluminów) stały się zaczątkiem Biblioteki Uniwersyteckiej².

Nie ulega wątpliwości, iż mankamentem księgozbioru organizowanej placówki uniwersyteckiej, wartościowego i świetnie zaopatrzonego w literaturę niemieckojęzyczną, był brak podstawowych dzieł literatury polskiej. Rychło też dyrektor biblioteki, dr Edward Kuntze, począł czynić zabiegi o dary książek z tej dziedziny, w rzeczy samej licznie składane przez instytucje naukowe z Warszawy, Krakowa, Lwowa i Wilna. Były pośród nich m.in. Polska Akademia Umiejętności w Krakowie, Towarzystwo Popierania Nauki Polskiej we Lwowie, Towarzystwo Naukowe Warszawskie, Kasa im. Mianowskiego i wiele innych. Kolejne dary spływały od redakcji edycji i czasopism, jak również wiele osób prywatnych przekazało powstającej Bibliotece Uniwersyteckiej swoje księgozbiory ${ }^{3}$.

Szczególnym nabytkiem, uzyskanym za zgodą Ministerstwa Wyznań Religijnych i Oświecenia Publicznego (czyli ówczesnego ministerstwa oświaty), był duży, bo liczony na 20 tysięcy woluminów zbiór książek ${ }^{4}$, pochodzących z likwidowanych rosyjskich bibliotek gimnazjalnych Kalisza, miasta położonego (podobnie jak Poznań) na terenie Wielkopolski, którego XIX-wieczne losy potoczyły się jednak zupełnie odmiennie aniżeli pozostałej części tej dzielnicy Polski. Wprawdzie pierwotnie rozbiory Rzeczypospolitej sprawiły, iż miasto dostało się we władanie Królestwa Prus, jednak ustalenia kongresu wiedeńskiego podzieliły Wielkopolskę pomiędzy Prusy i Cesarstwo Rosyjskie, Kalisz zaś, ówcześnie stolica departamentu, a później województwa i guberni, stał się miastem granicznym po rosyjskiej stronie kordonu. Stąd też zarówno dzieje miasta, jak i jego szkół i księgozbiorów potoczyły się innymi niż w Poznaniu kolejami, co sprawiło, że księgozbiory kali-

2 Przejęcia biblioteki cesarskiej na rzecz uniwersytetu dokonano 30 czerwca 1919 roku. Spór prawny, towarzyszący kwestii przejęcia, opisuje S. Vrtel-Wierczyński, op. cit., s. 5-6. Kwestię tę omawia również S. Kubiak w pracy Biblioteka Uniwersytecka im. Adama Mickiewicza w Poznaniu 1919-1966, Poznań 1967 („Prace Biblioteki Uniwersyteckiej w Poznaniu” 6).

3 Najcenniejsze z darów przekazanych w pierwszym dziesięcioleciu działania Biblioteki Uniwersyteckiej w Poznaniu wymienia S. Vrtel-Wierczyński, op. cit., s. 9-10. Problematyka ta jest również polem zainteresowań M. Głowackiej-Helak w artykule Dary dla Biblioteki Uniwersyteckiej w Poznaniu z lat 1921-1927, „Biblioteka” 2016, nr 20, s. 81-95.

4 Dane te podaje S. Vrtel-Wierczyński, op. cit., s. 10. 
skich gimnazjów, zbędne w szkołach po odzyskaniu przez Polskę niepodległości, okazały się interesujące dla tworzącej się Biblioteki Uniwersytetu Poznańskiego. Była ona niemal całkowicie pozbawiona lektur w językach słowiańskich, w tym w języku rosyjskim, dominującym we wspomnianych księgozbiorach szkolnych.

\section{GIMNAZJA KALISZA I ICH BIBLIOTEKI}

Kalisz, stare wielkopolskie miasto, szczycące się najstarszą w Polsce metryką pisaną ${ }^{5}$, pozostawał przez wieki jednym z najważniejszych ośrodków miejskich dawnej Polski (prawa miejskie od ok. 1257 roku), później zaś Rzeczypospolitej Obojga Narodów. Przez wieki też pełnił rolę stolicy jednego z dwóch województw wielkopolskich. Niemal tak samo stare są tradycje instytucji oświaty Kalisza, w tym najstarszej szkoły, dzisiaj I Liceum Ogólnokształcącego im. Adama Asnyka. Historię tej szkoły zapoczątkowuje szkoła kolegiaty pw. Najświętszej Marii Panny ${ }^{6}$, zamieniona później w kolegium arcybiskupów gnieźnieńskich, w pewnym momencie objęte opieką Akademii Krakowskiej. W 1584 roku szkołę przejęli jezuici, otwierając w Kaliszu jedno ze swych kolegiów, działające przez blisko 200 lat aż do 1772 roku, tj. do chwili kasaty tego zakonu i przejęcia szkół jezuickich przez Komisję Edukacji Narodowej. Od tego czasu szkoła działała nieprzerwanie jako placówka świecka, zmieniając jednak nazwy, najdłużej funkcjonowała jako Szkoła Akademicka Okręgowa (1783-1807), Szkoła Wojewódzka Kaliska (1819-1827), Wyższa Szkoła Realna (1845-1862) i Gimnazjum Filologiczne (1866-1916). W 1923 roku placówka została upaństwowiona i otrzymała imię jednego z najwybitniejszych swoich wychowanków - poety Adama Asnyka ${ }^{7}$.

Mimo trudnych lat pod zaborami stosunkowo długo dało się pod zaborem rosyjskim utrzymać polski charakter szkolnictwa. Najtrudniejsze czasy nastały po upadku powstania styczniowego 1863 roku. Od roku 1867 władze rosyjskie zaczęły likwidować względną autonomię Królestwa Polskiego i wprowadzać obowiązek nauczania wyłącznie w języku rosyjskim. Miało to naturalnie wpływ na kształt zbiorów szkolnej biblioteki, od tego bowiem czasu zakazany został zakup

${ }^{5}$ Chodzi o zapis poczyniony w II wieku naszej ery przez Klaudiusza Ptolemeusza w jego dziele Geografia, w którym wymienia on i określa współrzędne geograficzne miejscowości o nazwie „Kalisia”, utożsamianej przez wielu uczonych z współczesnym Kaliszem. W oparciu o to domniemanie w 1960 roku miasto obchodziło 1800-lecie istnienia. Por. B. Biliński, Dwa świadectwa antyczne. Kalisia Ptolemeusza i Halisii Tacyta, [w:] Osiemnaście wieków Kalisza. Studia i materiały do dziejów miasta Kalisza i regionu kaliskiego, t. 2, Kalisz 1961, s. 7-40; K. Jażdżewski, Ptolemeuszowa „Kalisia” i dzisiejszy Kalisz, „Folia Praehistorica Posnaniensia” 1, 1984, s. 187-190.

${ }^{6}$ Istnieje też domniemanie, iż najstarszą placówką szkolną Kalisza była szkoła kolegiaty św. Pawła, erygowanej wraz z powstaniem grodu na Zawodziu. Brak jednak wyraźnego potwierdzenia tego przypuszczenia.

7 Szkoła Kaliska. Dzieje I Liceum Ogólnokształcacego im. Adama Asnyka w Kaliszu, t. 1, pod red. E. Polanowskiego, Kalisz 1993, s. 201. 
książek polskich, w których miejsce gromadzono literaturę rosyjską. Dokonywano również selekcji księgozbioru, usuwając dawniej wydane publikacje, co przyspieszyło zmianę procentowego stosunku książek polskich do rosyjskich i spowodowało stosunkowo szybką rusyfikację biblioteki Gimnazjum Filologicznego, liczącej w chwili wybuchu I wojny światowej ok. 12 tysięcy woluminów ${ }^{8}$. Był to bez wątpienia najbogatszy księgozbiór wśród kaliskich placówek oświatowych.

Znacznie mniej wiemy o księgozbiorze najmłodszego kaliskiego gimnazjum rządowego ${ }^{9}$, jakim było gimnazjum realne, przeniesione do tego miasta w 1893 roku z Włocławka. Stanowiło ono konkurencję wobec istniejącego w Kaliszu od roku 1873 prywatnego gimnazjum Pawłowicza (później Jerzykowicza), które rzeczywiście po zainaugurowaniu nauki w nowej placówce uległo likwidacji, a jednocześnie było spełnieniem oczekiwań społeczności dwudziestotysięcznego z górą miasta gubernialnego, które potrzebowało placówki kształcącej młodzież na potrzeby rozwijającego się przemysłu i handlu. Szkoła ta zresztą, w przeciwieństwie do wyżej wspomnianego Gimnazjum Filologicznego, miała znacznie większy odsetek uczniów narodowości rosyjskiej. Również istniejąca w tej placówce oświatowej biblioteka dysponowała księgozbiorem w ogromnej części rosyjskojęzycznym.

Wybuch wojny w sierpniu 1914 roku stanowił tragedię dla Kalisza i jego mieszkańców ${ }^{10}$. Miasto zostało zniszczone, a wraz z nim także część zbiorów bibliotecznych. Podobny los spotkał biblioteki szkolne, ich ocalone części, wobec przeznaczenia budynków szkolnych na potrzeby władz okupacyjnych, zostały przeniesione do pomieszczeń zastępczych ${ }^{11}$. W 1916 roku zezwolono na wznowienie działalności gimnazjum męskiego, organizując tę szkołę pod nazwą Miejskiego Gimnazjum Filologicznego Męskiego w dawnym budynku szkolnym. Tam też złożono połączone zbiory bibliotek gimnazjalnych, podejmując jednak wobec nich pierwsze działania dopiero po odzyskaniu przez Polskę niepodległości w listopadzie 1918 roku.

\section{DROGA KSIĘGOZBIORÓW DO POZNANIA}

Miejskim Gimnazjum Męskim w Kaliszu, od początku istnienia tej formy szkoły, kierował dyrektor Stanisław Pacholski, filolog klasyczny, poznańczyk, ab-

8 Ibidem, s. $176-178$.

9 Wcześniej, bo w 1866 roku, powstało w Kaliszu gimnazjum rosyjskie żeńskie, wszystko jednak wskazuje, że jego księgozbiór nie wszedł w skład kolekcji przejętej przez Uniwersytet Poznański.

10 Istnieje obszerna literatura na temat zniszczenia miasta, w tym także losów księgozbiorów. Por. R. Bieniecki, B. Celer, Katastrofa kaliska 1914. Materiaty źródtowe. (Wybór), Kalisz 2014 tam też wyczerpująca bibliografia dotycząca tej tragedii.

$11 \mathrm{~W}$ pomieszczeniach gimnazjum męskiego umieszczono wojskowe władze miasta, a w budynku gimnazjum realnego szpital — Szkoła kaliska..., s. 117. 
solwent uniwersytetu w Berlinie, sympatyk Narodowej Demokracji ${ }^{12}$. Kluczową w tej kwestii sprawą jest zapewne jego znajomość z kaliskim archiwistą drem Leonem Białkowskim oraz prof. Józefem Kostrzewskim ${ }^{13}$, jednym z twórców Uniwersytetu Poznańskiego i wybitnym archeologiem, co stanowiło inspirację do przekazania księgozbiorów bibliotek gimnazjalnych Kalisza do zbiorów tworzącej się Biblioteki Uniwersyteckiej.

Zbiory te w rzeczy samej przechowywane były w dość trudnych warunkach. Sytuację tę opisywał towarzyszący prof. Kostrzewskiemu w kaliskiej peregrynacji L. Białkowski, ówcześnie już po opuszczeniu Kalisza dyrektor Archiwum Państwowego w Poznaniu ${ }^{14}$ :

Gimnazjum Miejskie Kalisz, ulica Grodzka.

Parter: spora sala, wzdłuż ścian szafy oszklone, prócz tego w poprzek sali takież szafy oraz na korytarzu, do Sali tej wiodącym, 4 szafy z drzwiami zabitymi. - Szafy atoli w Sali będące źle zabezpieczone, wiele zamków skręconych, otwarte. Kupy ksiąg wprost pod oknami złożone zgniły wskutek grzyba pełzącego [!] podłogą. Kupy te skazali na spalenie podpisany wraz z prof. dr. Kostrzewskim, ocalając tylko nieliczne tomy.

Szereg ksiąg w oczach moich zginął. Np. cenne dzieła Sziliera (hist[oryk] rosyjski) raz je widziałem, a po paru tygodniach już tylko zostały z nich okładki. Tajemnica w tym, że sala ta służy za jadalnię do śniadań dla uczniów gimnazjalnych o 12-ej w południe.

Biblioteka zawiera książki z dawnego Gimnazjum Męskiego (rosyjskiego), które w tymże właśnie gmachu się mieściło oraz inne zwiezione ze Szkoły Realnej. Prócz dawnych polskich, francuskich, niemieckich z XVIII i I połowy XIX wieku (które należy zostawić w Kaliszu jako podstawę przyszłej bibl[ioteki] publicznej), są tu tysiące dzieł naukowych i literackich w języku rosyjskim.

Dla slawistyki i historii przebogate zbiory: wydawnictwa Petersb[urskiej] Akad[emii] Umiej[ętności], periodyki rosyjskie (Żurnał Minist[erstwa] Proswieszcz[enija], Wiestnik Jewropy, Ruskaja Starina, Istoriczeskij Wiestnik etc. etc., nawet taka rzadkość jak Kijewskaja Starina). Dzieła Pogodina, Barsowa, Kotlarewskiego. W ogóle setki (dosłownie) dzieł czysto akademickich, przerastających nauczanie średnie.

Dyrektor Gimnazjum Miejskiego (Pacholski, filolog klasyczny, Poznańczyk, wychowaniec Uniw[ersytetu] Berliń[skiego]) godzi się na wydanie tych książek byle mu zostawić to, co potrzebne dla nauczania w gimnazjum i przedstawić polecenie Ministerstwa Ośw[iaty] na wydanie książek.

Wraz z prof. Kostrzewskim odsortowaliśmy i przygotowaliśmy w kilku szafach i zamknęliśmy (klucz u dyrektora) księgi, które naszym zdaniem mogą i powinny pójść do Poznań[skiego] Uniwer[sytetu].

12 E. Andrysiak, Pacholski Stanisław, [w:] Szkoła kaliska. I Liceum Ogólnoksztatcace im. Adama Asnyka w Kaliszu. Nauczyciele $i$ wychowankowie, t. 2, pod red. K. Walczaka, Kalisz 1998 s. 148-149. Nauczyciel łaciny i języka niemieckiego, kierował szkołą w latach 1916-1931. Jego poglądy polityczne były zresztą powodem usunięcia go, po dojściu do władzy obozu piłsudczyków, z gimnazjum kaliskiego i przeniesienia do żeńskiego gimnazjum w Płocku na stanowisko nauczyciela.

13 Inspiratorem był bez wątpienia Leon Białkowski, pełniący w latach 1919-1920 funkcję kierownika kaliskiego Archiwum Państwowego, choć niewykluczone, że S. Pacholski znał także prof. Kostrzewskiego, choćby z powodu wspólnych studiów na uniwersytecie w Berlinie.

${ }^{14}$ Białkowski Leon, [hasło w:] Stownik biograficzny archiwistów polskich, t. 1, Warszawa 1988.

Roczniki Biblioteczne 61, 2017

(C) for this edition by CNS 
Kalisz — to najbliższa biblioteka rosyjska w Kongresówce, która jest obładowana rossicami, a tych tu [tj. w Poznaniu] właśnie brak. Grzyb i kradzież zniszczą ja bezwzględnie.

Dr. Leon Białkowski, 18 II [19]21 15

Tekst ten charakteryzuje zarówno ideę wykorzystania nieprzydatnych w polskiej na powrót szkole książek rosyjskich, jak i stanowisko dyrekcji kaliskiej placówki wobec możliwości pozbycia się kłopotu z korzyścią dla organizowanej Biblioteki Uniwersytetu Poznańskiego.

Prace Józefa Kostrzewskiego i Leona Białkowskiego zabezpieczające księgozbiór przed rozproszeniem były początkiem zabiegów wokół przekazania książek uniwersytetowi. Dyrekcja kaliskiej szkoły nie mogła podjąć decyzji w tej sprawie, podobnie jak Kuratorium Okręgu Szkolnego Łódzkiego, któremu szkoła podlegała. Decyzję władne podjąć było MWRiOP, do którego już 25 lutego dyrektor Biblioteki Uniwersyteckiej zwrócił się z prośbą o przekazanie księgozbioru. W piśmie Edward Kuntze proponował następujące działania:

1) Ze względu na stan księgozbioru i niebezpieczeństwo jego rozproszenia Biblioteka Uniwersytecka do czasu podjęcia decyzji przez ministerstwo przejmie księgozbiór w depozyt.

2) Wyboru dzieł dokonają pracownicy biblioteki, przy czym dyrekcja szkoły będzie mogła zatrzymać te dzieła, które okażą się przydatne do nauki w gimnazjum lub w planowanej przyszłej bibliotece miejskiej w Kaliszu.

3) Koszt zapakowania książek i transportu do Poznania brała na siebie Biblioteka Uniwersytecka.

4) $\mathrm{W}$ razie braku zgody ze strony ministerstwa na przekazanie księgozbioru Biblioteka Uniwersytetu w Poznaniu zwróci na własny koszt księgozbiór do gimnazjum kaliskiego ${ }^{16}$.

Decyzję w tej sprawie MWRiOP podjęło 12 listopada 1921 roku po uzyskaniu pozytywnej opinii łódzkiego kuratorium. Sprawa jednak nie szła tak szybko, jak oczekiwał tego nadawca pisma, skoro jeszcze w grudniu tegoż roku prosił o wyznaczenie terminu powołania „komisji oddawczej”. Sam już 2 stycznia 1922 roku podjął pertraktacje z Senatem Uniwersytetu Poznańskiego na temat wyboru przedstawiciela uczelni, mającego uczestniczyć w wyborze i przejęciu książek, oraz pokrycia kosztów przejazdu i pobytu tegoż wysłannika. Ostatecznie Senat UP delegował do pracy w Kaliszu lektora języka rosyjskiego na Wydziale Filozoficznym UP, a jednocześnie nauczyciela w Gimnazjum św. Jana Kantego w Poznaniu, Piotra Żukowskiego. Przy okazji w połowie 1922 roku dyrekcja biblioteki zwróciła się do Kuratorium Okręgu Szkolnego Łódzkiego o zgodę na

15 Archiwum Biblioteki Uniwersytetu im. Adama Mickiewicza w Poznaniu (ABUAM). T. 1, Biblioteka Uniwersytecka 1920-1931, sygn. 224/217, k. 18-21. Za udostępnienie dokumentów i wielką życzliwość autorzy artykułu dziękują pani kustosz Małgorzacie Głowackiej-Helak.

${ }^{16}$ Ibidem, k. 22-23. Tekst ten skierowany był do dyrekcji gimnazjum w Kaliszu. Podobne pismo (identycznie datowane), skierowane do MWRiOP nie zawiera już sugestii możliwości zwrotu książek do Kalisza. 
zabranie dodatkowych książek z biblioteki gimnazjum, pisząc: „Wysłannik Biblioteki Uniwersyteckiej p. Żukowski, lektor języka rosyjskiego przy Uniwersytecie Poznańskim, zauważył przy okazji wyszukiwania książek rosyjskich, pewną ilość starszych książek, wydanych przed r. 1860 z zakresu nauk przyrodniczych, matematyki, rolnictwa, prawa i pedagogiki w językach polskim i francuskim. Książki te mające dziś znaczenie tylko historyczne, mają wielką wartość dla Biblioteki Uniwersyteckiej w Poznaniu" 17 .

Prośbę podobną dyrektor Kuntze złożył również na ręce naczelnika Wydziału Bibliotek Państwowych MWRiOP, Stefana Dembego, co najwyraźniej odniosło skutek, albowiem od 15 lutego do 15 lipca 1922 roku swoją pracę w Kaliszu podjął Piotr Żukowski, wybierając książki składowane w gimnazjum męskim i ekspediując je w przeszło 50 skrzyniach do Poznania. Prace te opisał w sprawozdaniu w sposób następujący:

Sprawozdanie z pracy nad segregowaniem książek rosyjskich w bibliotece Gimnazjum Miejskiego w Kaliszu (15 lutego-15 lipca 1922 roku)

Praca w Bibliotece Kaliskiej nastręczała nadspodziewane trudności, polegające na tym, że lokal nie posiada pieców ani żadnych lamp, wskutek tego w lutym i marcu pracę wypadało zredukować do trzech lub czterech godzin dziennie. Wskutek niesłychanego spustoszenia, wywołanego przez grzyb, który zamienił znaczną część podłogi i część szaf na próchno, a blisko tysiąc książek na pagórki z ciasta papierowego (te książki leżały na gnijącej podłodze) — powietrze w lokalu nawet przy otwartych obecnie oknach jest tak przepełnione zapachem stęchlizny, że praca ponad trzy godziny z rzędu, a sześć dziennie jest nie do wytrzymania. Dodać muszę, że przez pewien czas podczas okupacji niemieckiej lokal był używany jako klozet i dotychczas nie został należycie oczyszczony. Książki (oprócz tych które, jako gnijące zwały i kupy leżały na podłodze) mieściły się w 78 szafach — przeważnie w zupełnym pomieszaniu, wobec tego wypadało niemal każdą przeglądać z osobna. Paręset nawet tych książek wskutek wilgoci miały z obu stron kartki w liczbie kilku lub kilkunastu poprzyklejane do okładek; czasem trzy lub cztery książki były tak sklejone wysiękiem kleju z okładek i grzbietu, że stanowiły jedną całość. O ile były to dzieła cenniejsze, a takich było przeszło 100, musiałem ostrożnie scyzorykiem rozdzielać kartki, a później suszyć na słońcu, by uratować książkę dla polskiej nauki. Ponieważ szafy były wysokie aż do sufitu, wypadało posługiwać się drabiną — niestety bardzo marną i chwiejną, co znowuż miało skutkiem znaczne wyczerpanie energii. Wskutek przyczyn powyższych praca dłuż[sza] niż trzy dni była niemożliwą. Musiałem więc dojeżdżać co tydzień lub dwa tygodnie. Na również niespodziewane trudności natrafiłem podczas poszukiwań skrzyń i kantoru przewozowego. Dwa dni musiałem całkowicie poświęcić tej sprawie ponieważ ani w gronie nauczycieli gimnazjum, ani w hotelach nikt nie mógł udzielić mi potrzebnych informacji.

Wśród dzieł rosyjskich są komplety dzieł wyjątkowej wartości, naprz[ykład] „Żurnał Min[isterstwa] Nar[odnogo] Prośw[ieszczenija]" za sześćdziesiąt prawie lat, również mnóstwo bardzo cennych i rzadkich monografii z zakresu historii i historii literatury rosyjskiej oraz publicystyki.

W czerwcu wysłałem pierwszy transport, zawierający w 12 skrzyniach przeszło 2000 dzieł. Książki są przeważnie doskonale oprawione i w dobrym stanie. Niestety znaczną ilość, bo przeszło 200 cennych dzieł wypadło wyrzucić z powodu zniszczenia. Obecnie przygotowuję drugi transport - 13 skrzyń. Następnie wypadnie się zająć segregowaniem książek, które się miesz-

17 Ibidem, k. 32 — pismo z dnia 6 czerwca 1922 roku. 
czą w trzech dużych szafach w korytarzach. Szafy owe nie posiadają pułek [sic!] i są zapchane książkami jak cegłami od dołu do góry (w położeniu poziomem). Wobec tego, że w tej części gmachu przez wybite szyby i liche drzwi hulał wiatr, a temperatura w nieopalanym korytarzu była taką samą jak na ulicy, oraz wskutek tego, że do wieczora szkoła była przepełniona dziatwą (popołudniowe godziny zajmowało gimnazjum żeńskie) nie mogłem dotychczas rozpocząć pracy nad tą częścią księgozbioru. Również dopiero teraz mogę się zająć tymi książkami, które przypadkowo wykryłem w pokoju, mieszczącym sklep „Bratniej Pomocy” przy gimnazjum. Książki te zalegały podłogę na wysokość metra w ilości przypuszczalnie 1500 tomów. Rozsegregowanie wszystkich tych książek ukończę w jesieni, a gdy obejrzy je komisja oddawcza — zostanie przywieziona do Poznania ta ostatnia partia. Na końcu nadmienię, że na skutek mej prośby, p. Dyrektor Gimn[azjum] Kaliskiego zażądał zwrotu książek wypożyczonych internowanym w Szczypiornie i Kaliszu; w tych obozach znajduje się obecnie blisko 500 tomów, które powinny być przewiezione do Poznania. Dotychczas żądania p. Dyrektora nie odniosły skutku.

Co do ogólnej ilości tomów, przeznaczonych do Poznania, sięga ona 6000.

Piotr Żukowski

Lektor języka rosyjskiego

Poznań, 20 lipca $1922^{18}$

Wobec zgody ministerstwa na przekazanie uniwersytetowi innych niż rosyjskie książek Piotr Żukowski wrócił do Kalisza w 1923 roku, przesyłając kolejne partie księgozbioru. Problemem okazał się zwrot kosztów pobytu w Kaliszu, lektor bowiem parokrotnie zwracał się do Senatu UP o wypłacenie stosownych kwot, skrupulatnie załączając m.in. rachunki hotelowe i wyliczając liczbę przepracowanych dni i wysłanych skrzyń. Ostatecznie, co interesujące, uniwersytetowi udało się skłonić do poniesienia kosztów ministerstwo, albowiem to właśnie ta instytucja wypłaciła (dopiero w 1925 roku) Piotrowi Żukowskiemu 500 zł „remuneracji” za pracę wykonaną w Kaliszu ${ }^{19}$.

Przetransportowane do Poznania książki zostały wpisane do inwentarza akcesji — Księgi przybytków 1922a — od numeru 8250 do 15498 (wpisywanie rozpoczęło się 1 października 1924 roku). Dziś ma on znaczenie historyczne, zniszczenia zawartości Biblioteki UP w czasie II wojny światowej (a zapewne dotknęły i ten księgozbiór) spowodowały bowiem, iż książki kaliskie, podobnie jak ocalałe inne zbiory biblioteczne, zostały ponownie zinwentaryzowane i dzisiaj występują pod różnymi numerami inwentarzowymi. Śladem wspólnych losów pozostaje międzywojenny ekslibris wklejany do większości egzemplarzy, a zawierający zapis:

Biblioteka Uniwersytecka

w Poznaniu

Dar Ministerstwa

Bibl. Gimn. Kalisz Warszawa

18 Ibidem, k. 36-40.

19 Ibidem, k. 153 - decyzja MWRiOP w sprawie przyznania Piotrowi Żukowskiemu remuneracji, pismo z dnia 24 listopada 1925 roku. 


\section{ZAWARTOŚĆ}

W piśmie skierowanym do MWRiOP w Warszawie z początku 1921 roku dyrektor Pacholski pisał, że w znajdującym się w Gimnazjum Miejskim w Kaliszu, liczącym blisko 12 tysięcy tomów, księgozbiorze po dawnym gimnazjum rosyjskim przeważają wydawnictwa rosyjskie. Nie brakowało także książek polskich i francuskich, lecz przełożony gimnazjum zapewniał, iż „,ilość tych książek jest znikoma w stosunku do rosyjskich". Poza tym były wydawnictwa niemieckie „ostatnich czasów” ${ }^{20}$. Stefan Demby z kolei w piśmie do Departamentu II MWRiOP uzupełniał, że wydawnictwa rosyjskie dotyczą przeważnie filologii słowiańskiej, historii i archeologii prahistorycznej ${ }^{21}$.

Biblioteka zawierała również książki starsze, wydane przed 1860 rokiem, ,z zakresu nauk przyrodniczych, matematyki, rolnictwa, prawa i pedagogiki w języku polskim i francuskim"22.

Miejsca wydania druków rosyjskich to przede wszystkim Sankt Petersburg i Moskwa, poza tym Kijów, Odessa, Charków.

Tematyka przekazanych do Biblioteki Uniwersyteckiej zbiorów obejmuje różnorodne zagadnienia ${ }^{23}$, a zatem publikacje z zakresu geografii (1843, 1861-1863, 1872, 1873, 1883, 1895 i inne), mineralogii (1902), fizyki (1859, 1871, 1887-1888, 1908 i inne), biologii (1892) i botaniki (1888), algebry (1872, 1891), arytmetyki $(1836,1848,1853,1874,1885,1899)$, geometrii $(1877,1879,1903)$, logiki (1856, 1876, 1882), astronomii (1849), historii powszechnej i historii Rosji, teorii i historii literatury, literatury pięknej, językoznawstwa (1908), gramatyki (1843, 1864), historii gramatyki (1868, 1870), gramatyki różnych języków, filozofii (1901), psychologii, religii, piśmiennictwo z zakresu pedagogiki (dydaktyka - 1837, 1884, metodyka - 1873, historia pedagogiki - 1885), choć przeważnie były to podręczniki.

Literaturę piękną reprezentowały dzieła klasyków (w różnych wydaniach, choć niekompletne, oraz osobne wydania poszczególnych utworów): A. Puszkina (Evgenij Onegin, 1882; Narodnyja russkija skazki, 1873), N. Gogola (Taras Bulba, 1890), A. Tołstoja (Stichotworenija, 1857; Razskazy o Sevastopolskoj oborone, wyd. 2, 1890), I. Turgieniewa (Pévcy, 1884; Les i step, 1885; Pegas, 1885; Gamlet i Don Kichot, 1885), F. Dostojewskiego (Biednyje ljudi, wyd. 15, 1902), N. Gogola (Mertvyja duši, 1894), A. Ostrowskiego (Dramy, komedii, sceny i kartiny 1869-71, 1885).

${ }^{20}$ Ibidem, k. 26 - pismo S. Pacholskiego do MWRiOP w Warszawie z dnia 25 stycznia 1921 roku.

${ }^{21}$ Ibidem, k. [23?] — pismo Stefana Dembego do Departamentu II MWRiOP z dnia 18 lipca 1921 roku.

22 Ibidem, k. 32 - pismo dyrektora Biblioteki Uniwersyteckiej w Poznaniu do Kuratorium Szkolnego Województwa Łódzkiego w Łodzi z dnia 6 czerwca 1922 roku.

23 Informacje o edycjach i tytułach na podstawie Księgi przybytków 1922 a z ABUAM. 
Teoria i historia literatury to m.in. Pravila stichosloženija (1838), Istorija russkoj literatury (wyd. 2, 1875), wiele prac dotyczących Puszkina (np. Priloženija k socinen. A. Puškina, 1860; Junošeskie gody Puškina, 1888; A. Puszkin, wyd. 7, 1904).

Były też dzieła z zakresu filologii słowiańskiej (Učebnyj kurs teorii slovesnosti, 1883; Učebnik teorii slovesnosti, 1845, 1879, 1885; Učebnik russkoj slovesnosti, 1876).

Prace z zakresu historii powszechnej i historii Rosji to m.in. dzieła dotyczące rewolucji francuskiej (1894), roku 1612 (1900), wojny 1812 roku, imperatora Aleksandra III (1894), historii XIX wieku (1906-1907), Rosji i Serbii (1869) oraz podręczniki (1900).

Wydawnictwa w języku polskim to także w większości podręczniki (arytmetyka, geometria, algebra, trygonometria, gramatyka języka polskiego, francuskiego, niemieckiego, łacińskiego, rosyjskiego, greckiego, ortografia polska, historia powszechna, fizyka, chemia, zoologia), ponadto publikacje z zakresu rolnictwa, wydawnictwa religijne, pedagogiczne oraz związane ze szkolnictwem.

Na uwagę zasługują także czasopisma, choć były to zarówno pojedyncze roczniki, jak i tytuły liczące po kilka roczników (nie zawsze kompletne), np. „Narodnaja škola” (1887, nr 1-12), „Russkij pedagogičeskij věstnik” (1860, z. 1-12; 1861, z. 2-12), „Rus” (R. 3-6, 1883-1886), ,Věstnik inostrannoj literatury” (R. 10, 14-16, 23, 1906-1913), „Věstnik vsemirnoj istorii” (1902), „Věstnik archeologii i istorii” (1885-1892), „Chudožestvennaja gazeta” (1840), „Staryje gody” (1911, nr 1-12; 1913, nr 7-9).

Trudno też pominąć grupę starodruków z kaliskich gimnazjów liczącą ponad 100 tytułów z lat 1593-1800 w języku polskim, francuskim, niemieckim i greckim.

Jest również akcent kaliski, czyli tytuły drukowane w Kaliszu, a mianowicie Bajki Ignacego Krasickiego (1830), O podwojeniu korzyści i znacznym pomnożeniu nawozu zwierzęcego z używania ziemi na podściótkę w stajniach autorstwa warszawskiego lekarza weterynarii Jakuba Lewandowskiego (1847) oraz Sbornik stereometrii... Apolinarego Klonowskiego (1910).

\section{ZNACZENIE KSIĘGOZBIORÓW DLA BIBLIOTEKI UNIWERSYTECKIEJ}

Księgozbiory kaliskich gimnazjów, które trafiły do Biblioteki Uniwersyteckiej w Poznaniu, stały się bez wątpienia ważnym nabytkiem dla młodej placówki, gromadzącej ówcześnie bardzo intensywnie literaturę polską i szerzej słowiańską. W ten sposób literatura (zwłaszcza rosyjska), niemająca po 1918 roku racji bytu w polskiej szkole, znalazła odpowiednie miejsce w bibliotece naukowej. Należy zwrócić uwagę, że alternatywą mogło się stać zniszczenie owych księgozbiorów, po odzyskaniu niepodległości coraz mniej potrzebnych w placówkach oświaty, choćby ze względu na pojawiającą się w tych czasach coraz liczniej literaturę polską. 
Paradoksem jest, iż, być może, fakt przekazania tego księgozbioru pozwolił na zachowanie w polskich zasobach bibliotecznych interesującego fragmentu XIX-wiecznej literatury rosyjskiej, który w ten sposób zapewne uniknął losu 100 tysięcy książek polskich i żydowskich, stanowiących własność międzywojennych placówek bibliotecznych Kalisza, zrzuconych wraz z gruzem i śmieciami w koryto dawnej fosy miejskiej przez okupantów w czasie II wojny światowej. Dzisiaj fakt ten upamiętnia w Kaliszu pomnik Książki, przynosząc jakże inne konstatacje wobec mądrego wykorzystania pozostałości po rządach zaborczych. Książki pochodzące z bibliotek gimnazjalnych Kalisza pomogły zbudować w Uniwersytecie Poznańskim rusycystykę, dziś zaś są nadal ważną kolekcją książki XIX-wiecznej, w jej interesującym kształcie merytorycznym i wydawniczym, zasługującym na dalsze wnikliwe badania.

EWA ANDRYSIAK, KRZYSZTOF WALCZAK

\section{RUSSIAN BOOK COLLECTIONS OF KALISZ SECONDARY SCHOOLS AS AN EXAMPLE OF A UNIVERSITY LIBRARY COLLECTION IN POZNAŃ}

\section{Summary}

The University Library in Poznań has among its holdings substantial fragments of old libraries from secondary schools in Kalisz. They contain primarily Russian-language literature owing to the fact that until 1914 the schools functioned within the Russian school system. The article is the first report on the contents of these libraries, also explaining how the books found their way to the University Library in Poznań.

KEY WORDS: University Library in Poznań, Kalisz, secondary school libraries 